\title{
Pricing Color Intensity and lightness in Contemporary Art Auctions
}

Citation for published version (APA):

Pownall, R., \& Graddy, K. (2016). Pricing Color Intensity and lightness in Contemporary Art Auctions.

Research in Economics, 70(3), 412-420. https://doi.org/10.1016/j.rie.2016.06.007

Document status and date:

Published: 01/09/2016

DOI:

10.1016/j.rie.2016.06.007

Document Version:

Accepted author manuscript (Peer reviewed / editorial board version)

Document license:

CC BY-NC-ND

\section{Please check the document version of this publication:}

- A submitted manuscript is the version of the article upon submission and before peer-review. There can be important differences between the submitted version and the official published version of record.

People interested in the research are advised to contact the author for the final version of the publication, or visit the DOI to the publisher's website.

- The final author version and the galley proof are versions of the publication after peer review.

- The final published version features the final layout of the paper including the volume, issue and page numbers.

Link to publication

\footnotetext{
General rights rights.

- You may freely distribute the URL identifying the publication in the public portal. please follow below link for the End User Agreement:

www.umlib.nl/taverne-license

Take down policy

If you believe that this document breaches copyright please contact us at:

repository@maastrichtuniversity.nl

providing details and we will investigate your claim.
}

Copyright and moral rights for the publications made accessible in the public portal are retained by the authors and/or other copyright owners and it is a condition of accessing publications that users recognise and abide by the legal requirements associated with these

- Users may download and print one copy of any publication from the public portal for the purpose of private study or research.

- You may not further distribute the material or use it for any profit-making activity or commercial gain

If the publication is distributed under the terms of Article $25 \mathrm{fa}$ of the Dutch Copyright Act, indicated by the "Taverne" license above, 


\title{
Pricing Color Intensity and Lightness in Contemporary Art Auctions *
}

\author{
Rachel A J Pownall ${ }^{\dagger} \quad$ Kathryn Graddy $\ddagger$
}

June 26, 2016

\begin{abstract}
Color plays an important part in modern life and influences our decision making process. However, little is known about how the different attributes of color, namely intensity and lightness, influence price. By analyzing auction data for paintings we can put a price on these attributes of color. Using a unique set of data for Contemporary artworks of Andy Warhol prints, we are able to observe the influence of intensity and lightness using RGB values as explanatory variables on prices achieved at auction. Controlling for other hedonic characteristics, our empirical results find significant evidence of intense colors fetching a premium over equivalent artworks which are less intense in color. Furthermore, darkness carries a premium over lightness.
\end{abstract}

\footnotetext{
${ }^{*}$ The authors gratefully acknowledge the helpful comments given by participants at the 2014 Association of Cultural Economics Meetings in Montreal, the 2014 Annual Art Market Symposium in Luxembourg, the Art Wealth Management Forum in Nanjing, the NIAS New Cultural Commons workshop in Wassenaar, the 2013 Southern Economic Association Meetings in Tampa; seminar participants at Erasmus University Rotterdam, and particular thanks to Anna Dempster, Tim Fry, Rik Peeters, Luc Renneboog, and Marshall Xiaoyin.

${ }^{\dagger}$ Department of Finance, Maastricht University. Tongersestraat 53, 6200 MD Maastricht, The Netherlands, and TIAS School for Business and Society, Tilburg University, The Netherlands. r.pownall@maastrichtuniversity.nl

‡Department of Economics, Brandeis University, kgraddy@brandeis.edu
} 


\section{Introduction}

Sensational prices achieved at Contemporary art auction sales for Andy Warhol's artworks hit the headlines. In 2007 his Green Car Crash sold for an auction record price of $\$ 71.72$ million dollars, only to be superseded by his Silver Car Crash, selling in November 2013, for $\$ 104.5$ million dollars. His iconic vivid images have reached high prices, but to what extent is the intensity of color or lightness of a work of art related to the price reached at auction? In this paper we address this question using prices of Warhol paintings sold at auction over one single year to focus on the current market for Warhol's artworks and determine the importance of specific attributes of color to price in the market. We use digital images of Andy Warhol's works to determine the color attributes.

A primary methodological issue when studying color is that color varies on multiple attributes. Scientists often break down color into hue (wavelength; what most people think of as color), chroma (the intensity, saturation, or vividness of the color), and lightness (the white to black, or grayscale property), ${ }^{1}$ Fairchild [2013], Elliot and Maier [2014]. Digital images are stored as pixels. Each pixel is expressed as a vector of the three colors, denoted RGB color for red $(R)$, green $(G)$ and blue $(B)$; stored as 8-bit RGB matrices. With RGB color expressed as an integer between 0 and 255, colors are formed from various combinations of red $(\mathrm{R})$, green $(\mathrm{G})$ and blue $(B)$. In this paper, we specifically investigate intensity and lightness by using RGB values. We allow the effects of intensity to vary by red, green and blue hues.

We chose prints by the artist, Andy Warhol, to study the effect of color attributes

\footnotetext{
${ }^{1}$ In this research, we will refer to chroma as intensity, to the grayscale property as lightness and to color as hue, ideally avoiding confusion.
} 
on value. In the 1960s Warhol created, amongst other work, a large number of massproduced silkscreen images. He often focused on a number of iconic celebrities, such as Marilyn Monroe, Chairman Mao, and Elizabeth Taylor for his artworks. Many of these prints belonged to a number of limited editions and hence have the advantage that they can be compared to each other at different times of sale, and also can be compared to other artworks of the same image, but which differ only in their attributes of color.

This paper proceeds as follows. In section 2 we provide background information on the study of color in art. In section 3 we discuss the data and our choice of works by Andy Warhol. In section 4 we provide details on the methodology we use to analyze color. Section 5 presents our estimation methodology, Section 6 discusses results, and section 7 concludes our analysis.

\section{The Study of Color}

Scientists have long been preoccupied with the influence of hue (color) on emotion. In the 19th century, von Goethe and Eastlake [1840] speculated that some hues induce positive feelings such as warmth and calm, whereas others induce coldness or restlessness. While few have looked at hue and willingness to pay, academics interested in marketing have studied color associations in relation to shopping patterns, (Bellizzi and Hite [1992], Crowley [1993], and Brengman and Geuens [2004]). Bazley et al. [2016] analyse the influence of the color red in a financial setting, where being in the red is commonly associated with loss making, and analyse whether red activates more risk averse behaviour and pessimistic expectations of financial outcomes.

Historically, color has been important to the price of paintings. Etro and Pagani [2012] note that the colors gold and ultramarine blue were more expensive as, inputs 
and patrons paid more for the artist to use these colors. While this reflected the pure cost of the pigments, paintings with these colors were perceived to be more valuable because of their cost.

Stepanova [2016] has recently studied the impact of hue on price for Picasso paintings. Using the average distance between colors in RGB space, she finds that contrastive colors tend to fetch higher prices at auction. She also notes that for some contemporary artists, namely artists working in the style of Abstract Expressionism noted as Color Field, color becomes an end in itself.

Recent work in psychology and vision science has focused not only on hue, but also on the color attributes of intensity and lightness, among other attributes. One of the first papers to look at the effect of these different attributes on the brain was Livingstone and Hubel [1988], who found evidence that the visual selectivity in color and depth perception seem to be derived from differing and distinct pathways. An up to date summary on scientific work on the many attributes of color can be found in the recently published 'Handbook on Color Psychology', Elliot et al. [2015]. This paper is one of the very first empirical papers to look at the effect of color intensity and lightness on auction price.

Amongst philosophers and art historians, color has not always achieved a place of prominence. Until the 16th century, the importance of drawing versus color (disegno and colore) was hotly debated, with many critics, philosophers and art historians believing that the importance of a painting lies in its design rather than its execution. Roger de Piles was an important player in this debate. For many, color was considered mere ornamentation. Some art theorists believe this view began with Plato, with Aristotle clearly defining the dichotomy between color and drawing. According to Lichtenstein 
[1993], Plato condemned painting because of its colors and Aristotle reprieves it for its drawing [p. 62]. In 1673 de Piles published the Dialogue sur le Coloris in support of the Venetian style and their use of color. The Venetians were known for the intensity of color in their paintings, especially blues. Later de Piles chose 58 famous artists and decomposed these artists's styles into the areas of composition, drawing, color and expression, rating each artist on a 20 point scale in each of these categories. These ratings were published in his 1708 work, Cours de Peinture par Principes, in a table known as his "Balance des Peintres." Graddy [2013] finds that the importance of de Pile's color rating on price appears to have marginally increased over time, whereas the importance of drawing has marginally decreased.

Etro and Pagani [2013] also discuss the importance of colors. They note that the use of bright and sparkling colors by the artists such as Tiepolo, Ricci, and Caneletto influenced the development of the rococo style.

\section{Andy Warhol and The Auction Data}

During the 1950s Pop Art emerged in the US, and Andy Warhol was a leading artist in this movement. He used nonrepresentational color and form to convey different sensations. To determine the influence of color intensity and lightness on price, we use a natural setting to single out as much as possible the element of color on price. We focus on a single artist, Andy Warhol, since the artist is the most predominant and important factor influencing the price of art. The variation in price across a particular artist's paintings depends on other defining characteristics of his or her work. For example, the genre, the medium, the size, and the time during his or her life when the artwork was painted. Other factors which also play a role are whether the artwork was 
exhibited and where the artwork was auctioned. These factors influence the quality and the reputation associated with the artwork. We therefore include artworks which are similar in size, genre and auction location. We also choose to focus on contemporary art, which is vibrant in color and of which there are a variety of different color variants occurring of the same image.

We also collect information on the number of editions of the artwork which were produced at the time. This means that we can control the price at auction for the relative scarcity of the work; uniqueness has a value. Generally speaking, the greater the number of the edition printed at the time of creation the lower the art sales price. For every artwork sold in our data set we also collect information on the maximum number of editions associated with the artwork. We use art auction data. Ashenfelter and Graddy [2003] provide an overview of the art auction process.

Warhol paintings are not only iconic, well-known and reach high prices, but there is also enough turnover in the market and market liquidity such that we have enough variation in the type of artworks and images which were sold during the time period under investigation. They also offer us an ideal control group to work with. Many of the images are produced using different color attributes on the same image. We condition our data sample to all Warhol artworks, which have been sold at major auction houses during $2012^{2}$. We are not able to obtain prices of Warhol artworks sold by dealers or privately for the sample period. We also have information on the location of the auction houses as well as the name of the house. This means that we are able to control for reputational effects and potential quality effects for sales occurring at the more well-known and prestigious auction houses globally. As mentioned earlier

\footnotetext{
${ }^{2}$ We thank Anna Butz for her research assistant collecting the sample.
} 
an important factor in the determinant of price is the number of editions which were printed at the time of creation. All sales include the maximum number of prints in the edition. For this variable there is a minimum of 1 and a maximum of 2000 in our sample of 178 paintings. The average auction price for our sample during 2012 is just over $\$ 40,000$ US dollars ${ }^{3}$. Since we focus on prints, the highest price obtained in our sample at auction is $\$ 218,500$ and the lowest price was $\$ 2,250$. For sales not occurring in USD the exchange rate was used on the day of the sale and all prices are compared in US dollars. We also have information on the size of the artworks and the material used. The larger the size of the artwork, typically the higher the value, and hence the greater the price. See Table 1 for summary statistics. Later, in the empirical section we return to our findings, where we expect the price to be negatively influenced by the number of prints in the edition.

Insert Table 1 here.

To investigate how color attributes influence prices for Andy Warhol artworks, we control for the artwork characteristics and focus on how color is represented. In the following section we introduce the color variables, and how they are estimated from the digital images analyzed from the online auction catalogues.

\footnotetext{
${ }^{3}$ We transform all sales prices to US currency on the date of sale
} 


\section{Quantifying Color}

\section{$4.1 \quad$ Intensity}

Digital images are represented by pixels, the larger the number of pixels, the higher the quality of the image. Each pixel is expressed as a vector of the three colors, denoted RGB color for red (R), green $(\mathrm{G})$ and blue $(B)$; stored as 8-bit RGB matrices. With RGB color expressed as an integer between 0 and 255, colors are formed from various combinations of red $(\mathrm{R})$, green $(\mathrm{G})$ and blue $(\mathrm{B})$. For example, dark red would be represented as $(139,0,0)$ and light red would be represented as $(255,0$, 0) Color combinations are slightly more complicated. For yellow we would need equal amounts of red and green (255 255 0). The lower the RGB color the darker the image. For a darker shade of yellow, we would lower the amount of red and green by an equal amount, i.e. (200 200 0). Likewise, the larger the RGB number the whiter the image. However, to achieve a lighter yellow than that produced by (255 2550 ), we need to increase the amount of blue, for example to (255 255 140).

An RGB histogram can be used to illustrate the tonal values for each of the three RGB color channels. We take the average of the $\mathrm{R}, \mathrm{G}$, and $\mathrm{B}$ pixel tonal values over the whole painting as a proxy for the amount of red, green and blue in the artwork. This gives us a first indication of how the intensity of color differs across our database of artworks. This estimate expresses the amount of RGB color in each image, and at this stage does not provide any interaction of color or variation across an artwork or between parts of an artwork. We take the simple average of the R, G, and B pixel values

over all pixels in the image. We dropped images with pixel values of less than 200x200, resulting in a minimum definition of at least 4000 pixels per image. For robustness we 
check that this minimum pixel value accurately captures the estimates of the average R, G and B colors. We find that using a random sample of images with differing pixel quality that the estimates of RGB are robust to this minimum pixel value. Overall, the larger the red value, the less intense the red is in the image, the larger the green value, the less intense the green in the image, and the larger the blue value, the less intense the blue hue is in the image.

Insert Figure 1 here.

Figure 1 gives an example of one of the 19 Marilyn images in our data sample. Using the K-means clustering approach, which segments colors using an automated process in to a choice of a number of pre-specified clusters. We first cluster across the three colors, red, green and blue, as shown in Figure 2.

Insert Figure 2 here.

\subsection{Lightness}

When the color numbers of a pixel are equal we obtain a grayscale image; ranging from pure black (0R 0G 0B) through to gray (127R 127G 127B), to pure white (255R $255 \mathrm{G} 255 \mathrm{~B})$. In order to estimate the grayscale value, we use the matlab command, $\mathrm{I}=$ rgb2gray $(\mathrm{RGB})$, which converts the RGB color image to a grayscale image by eliminating the hue and saturation information while retaining the luminance. ${ }^{4}$ Again we will also use the average of the grayscale obtained from all pixels. Since this is a one dimensional matrix of pixels we can also estimate the standard deviation of these grayscale pixels. The average grayscale gives an indication of the color intensity in the

\footnotetext{
${ }^{4}$ rgb2gray converts RGB values to grayscale values by forming a weighted sum of the R, G, and B components: $0.2989 * \mathrm{R}+0.5870 * \mathrm{G}+0.1140 * \mathrm{~B}$
} 
overall artwork. The higher the number the lighter the artwork and the less intense the color.

\section{3 $\quad \mathrm{L}^{*} \mathrm{a} * \mathrm{~b}$ color space}

The human eye is sensitive to only a narrow band of frequencies. Humans therefore perceive color differently than depicted by digital tonal values. For example, the human eye is more sensitive to green, which lies in the center of the visible light spectrum, than to other colors. We therefore take into account the three dimensional plan, $\mathrm{L} * \mathrm{a} * \mathrm{~b}$. L represents luminosity as a function of RGB colors. The second plane, the chromaticity layer $a$, indicates where the color falls along the red-green axis. The $b$ chromaticity layer indicates the third plane where the color falls along the blue-yellow axis.

The $\mathrm{L}^{*} \mathrm{a} * \mathrm{~b}$ color space, sometimes known as the CIE $\mathrm{L}^{*} \mathrm{a}{ }^{*} \mathrm{~b}$ color space was first developed by the Commission internationale de l'Eclairage proceedings in 1931, Guild [1932]. Algorithms that use the CIE L*a*b color space to process images are generally perceived to be more inline with the way that humans perceive color. We use the Matlab command RGB2Lab. Matlab defines the RGB2Lab command as a "nonlinear transformation of RGB where the Euclidean distance between two colors is equal to their perceptual distances." 5

Using the Image-Processing software in Matlab we are able to determine the average values for the three layers. We effectively transform the image from RGB colorspace to the $\mathrm{L} * \mathrm{a} * \mathrm{~b}$ colorspace and estimate the average over all the pixels of the variables for the Luminosity layer, (L-mean), the red-green layer (a-mean) and the blue-yellow axis (b-mean). These three layers are shown for the Marilyn print depicted in Figure 3.

\footnotetext{
${ }^{5}$ www.mathworks.com/matlabcentral/fileexchange/24009-rgb2lab
} 
Insert Figure 3 here.

\section{Estimation}

Recent evidence suggests that the price of a painting can (to a certain extent), be broken up into a number of various constituents, or bundles of characteristics, which are valued separately. This approach enables us to use quantitative models to analyze art prices (Pesando and Shum [1999]).

To determine if color has additional value, we estimate an hedonic pricing model which attributes values to a number of hedonic characteristics, and we include color as an explanatory variable. An hedonic price function can be used when an item or product has a number of elements which all add value to the price of the item. We use the hedonic function to estimate the degree to which painting characteristics help explain art prices. It assumes that art buyers value a number of characteristics separately and the function expresses the price of a good in terms of all its relevant factors.

For example, the model estimates the average contribution made to price by a larger painting than a smaller painting by the same artist, or the premium that buyers are willing to pay for an oil painting over a watercolor. The method enables us to decompose the prices paid for paintings into a number of characteristics related to the artwork itself, such as size, genre, technique, medium, date, and also characteristics of the artist, such as age or reputation, which we write compactly, in a semi- logarithmic functional form, with the characteristics listed in a vector, $X$.

The model relates the natural logs of real USD prices to year dummies, while controlling for this wide range of hedonic characteristics. 


$$
P=\exp ^{X \beta e}
$$

Taking logs,

$$
\ln (P)=X \beta+e,
$$

since $\beta$ and $e$ are unknown true parameters, we can estimate these by running a regression of the various characteristics on price as

$$
\begin{gathered}
\ln (P)=X b+\epsilon \\
\ln \left(P_{k t}\right)=\alpha+\sum \beta_{t} X_{n t}+\sum \gamma_{t} D_{k t}+\epsilon_{t}
\end{gathered}
$$

Where $P_{k t}$ represents the price of art object $\mathrm{k}$ at time $\mathrm{t}, X_{n t}$, is the value of the characteristic $\mathrm{n}$ of item $\mathrm{k}$ at time t. Often a time dummy is included to control for time $D_{k t}$ that equals one if object $\mathrm{k}$ is sold in period $\mathrm{t}$, (and zero otherwise), but in our case we only include sales from a single year. The coefficients reflect the attribution of a relative shadow price to each of the $\mathrm{n}$ characteristics, while the exponentials of the estimates of $\gamma_{t}$ can be used to construct an art price index that controls for time variation in the quality of the art sold. The appeal from using a semi-log model is in the interpretation of the coefficients. The coefficients from the hedonic regression are approximately the percentage change in the price of the artwork given a unit change in the independent variables. The estimated coefficients represent the consumer's willingness to pay a premium for a particular characteristic.

In the literature, a number of hedonic studies have taken this approach to ana- 
lyze art prices. The main hedonic studies are Rengers and Velthuis [2002], Frey and Eichenberger [1995], Buelens and Ginsburgh [1993], Agnello and Pierce [1996], Galenson and Weinberg [2000], Renneboog and Van Houtte [2002], Rengers and Velthuis [2002], and Velthuis [2003]. Some general findings which these studies find support for are as follows. Firstly, paintings are more expensive than artworks made in edition. This supports the general hypothesis that consumers value artworks according to the proximity to the creator. Larger paintings are on average more expensive, up to a certain point, after which this effect is significantly reduced. The number of works an artist sells has a positive effect on price Rengers and Velthuis [2002]. The coefficients vary over time which indicates changing tastes, and portraits are for example more expensive than landscapes Buelens and Ginsburgh [1993]. Recently, Hellmanzik [2016] shows that the presence of Impressionist painters at 19th century exhibitions is correlated with their current prices at auction.

Indicator variables which assign a value of 1 if positive or zero otherwise are also included, such as the presence of a signature. Further indicator variables can take a value of 1 if assigned to a particular artist, auction house, or medium. Studies have even included the subject, prominence in the artists career, whether exhibited, and the condition. The effect of death is ambiguous. Buelens and Ginsburgh [1993] find that artworks by living artists are sold at a premium, indicated by a positive coefficient on a dummy variable for alive. Ursprung and Wiermann [2011] find a nuanced effect, which depends upon the age of the artist's death. Although some factors are hard to quantify, such as who attends a sale, or prominence in the collection, they can indirectly be incorporated into the estimate. Indeed the inclusion of price estimates in hedonic price regressions, since their introduction in the mid-1970's, means that not only can 
indexes be created over time, but also they have significantly improved the ability of these models to explain the heterogeneity of art prices.

By focusing on one particular artist, we are able to control for a large part of the heterogeneity which occurs in pricing the cross-section of artworks. Our hedonic regression includes a number of attributes related to the artist, the work and the sale. Specifically, we include the print edition, size, date, location of sale, Christies or Sotheby's, and Medium.

We further add to this literature by studying how the differences in art prices across paintings are influenced by the intensity of color and grayscale, by including RGB values both separatly and together, the transformation of RGB values in $\mathrm{L}^{*} \mathrm{a} * \mathrm{~b}$ as described above, and grayscale.

\section{Results}

In Table 2 we present the results from the hedonic regression focusing on intensity. ${ }^{6}$ For our sample we find strong support for the size and the date in line with previous literature. The date of creation is highly significant, indicating that his earlier works are worth more than Warhol's later creations. Sotheby's and Christies have not attracted higher sales than other auction houses for the sample of Wahrhol artworks during 2012. We also control for sales occurring in differing locations with dummies included for both London and New York.

In columns one to three of Table 2, we include the average pixel values for the RGB factors. We find that the coefficient on all RGB factors to be statistically significant

\footnotetext{
${ }^{6}$ Note that the $R_{2}$, at .2 , is relatively low for a hedonic index. This is because we only have one artist and one year of sales. Much of the explanatory value in a hedonic regression comes from the artist and year fixed effects.
} 
at the $5 \%$ level for all three colors. The negative coefficient represents that the lower the RGB values, the higher the log art price. Since the variables are denoted in logs, we can express the value in terms of percentages. The estimated coefficient from the hedonic regression range from -0.003 from red to -0.004 for green and blue. This means that a 1 unit reduction in the mean value of the RGB colors are approximately worth an additional $0.3 \%$ to $0.4 \%$ more in price. Since the maximum value of the RGB colors is 255 , a 10 point reduction in color tone, results in a $3-4 \%$ increase in price. The interpretation is that the intensity of color significantly increases price. There is no significant difference in contribution between red, green and blue. In the final column, 4, we include all three colors, which when occur together suffer from multicollinearity, with none of the resulting coefficients statistically significant. ${ }^{7}$.

Insert Table 2 here.

In our second set of regressions, we transform the RGB values into $L^{*} a * b$ values using a three-dimensional layering scale representing luminosity (L), a red-green plane (a), and a blue-yellow plane (b). When using this transformation, as shown in Table 3, we find that only the luminosity layer is priced in the hedonic function. The coefficient is statistically significant at the $5 \%$ level and the value for the coefficient is -.004, which represents a $0.4 \%$ increase in price per unit reduction in the level of the luminosity. Note that the coefficients on the covariates are identical in column 4 of Tables 2 and 3 . This results because $\mathrm{L}^{*} \mathrm{a} * \mathrm{~b}$ is a direct transformation from RGB.

Insert Table 3 here.

\footnotetext{
${ }^{7}$ This regression, with all three colors included, also confounds intensity with grayscale, as grayscale is just a linear combination of RGB
} 
Finally, as shown in Table 4, using the grayscale variables in the hedonic function we again find a significant negative coefficient on the average value for the grayscale. Since we have one dimension of values, we can include the measure for the standard deviation of the gray value. This represents the variation in the gray shading in the artwork. This, however is not statistically significant.

Insert Table 4 here.

To gauge this color difference in Figure 4 we show the scale from white to black; each $10 \%$ range representing 25.5 units on the RGB color scale. A movement from one block to the next, from light to dark, as depicted in Figure 4, is worth an additional $4 \%$ in price. Given that the average price of paintings sold in the sample is just above $\$ 41,000$ dollars, this represents an additional value of $\$ 1250$ per block of shading. Our results here are consistent with intensity or saturation resulting in a higher price.

\section{Insert Figure 4 here.}

\section{Conclusion}

Focusing on a one year sample period enables us to gain a snapshot of how the intensity of color and lightness of a work are priced. The larger the subsample of icons such as Marilyn, Mao and even the $\$$ sign images, the more precise we can be. Even if only in terms of Andy Warhol's iconic dollar signs, in one sense, we are able to put a price on the color (attributes!) of money.

Using a unique set of images for contemporary art sales in 2012, for Andy Warhol artworks sold at auction, we find significant evidence that color intensity influences 
price. We find similar results when analysing the data using the luminosity factors, which are more representative of the way the human eye processes color. The color that the eye is least sensitive to is the color which is worth the most in terms of price increase per unit of reduction in the RGB color intensity. Controlling for other hedonic characteristics, empirical results find significant evidence of darker colors carrying a significant and robust premium than equivalent artworks which are less intense in color.

Our findings reveal how the digital representation of color images and in particular the luminosity of color influence prices observed in auction markets for contemporary art. Our study can aid the development of how human perception of color is translated into value. 


\section{References}

Richard J Agnello and Renée K Pierce. Financial returns, price determinants, and genre effects in american art investment. Journal of Cultural Economics, 20(4):359-383, 1996.

Orley Ashenfelter and Kathryn Graddy. Auctions and the price of art. Journal of Economic Literature, 41(3):763-787, 2003.

William J Bazley, Henrik Cronqvist, and Milica Mormann. In the red: How color affects investors and financial markets. Unpublished manuscript, 2016.

Joseph A Bellizzi and Robert E Hite. Environmental color, consumer feelings, and purchase likelihood. Psychology \& marketing, 9(5):347-363, 1992.

Malaika Brengman and Maggie Geuens. The four dimensional impact of color on shoppers emotions. Advances in consumer research, 31(1):122-128, 2004.

Nathalie Buelens and Victor Ginsburgh. Revisiting baumol's art as floating crap game. European Economic Review, 37(7):1351-1371, 1993.

Ayn E Crowley. The two-dimensional impact of color on shopping. Marketing letters, 4(1):59-69, 1993.

Andrew J Elliot and Markus A Maier. Color psychology: Effects of perceiving color on psychological functioning in humans. Annual review of psychology, 65:95-120, 2014.

Andrew J Elliot, Mark D Fairchild, and Anna Franklin. Handbook of Color Psychology. Cambridge University Press, 2015.

Federico Etro and Laura Pagani. The market for paintings in italy during the seventeenth century. The Journal of Economic History, 72:423-447, 6 2012. ISSN 1471-6372.

Federico Etro and Laura Pagani. The market for paintings in the venetian republic from renaissance to rococò. Journal of Cultural Economics, 2013.

Mark D Fairchild. Color appearance models. John Wiley \& Sons, 2013.

Bruno S Frey and Reiner Eichenberger. On the rate of return in the art market: Survey and evaluation. European Economic Review, 39(3):528-537, 1995.

David W Galenson and Bruce A Weinberg. Age and the quality of work: The case of modern american painters. Journal of Political Economy, 108(4):761-777, 2000. 
Kathryn Graddy. Taste endures! the rankings of roger de piles ( 1709) and three centuries of art prices. The Journal of Economic History, 73(03):766-791, 2013.

J. Guild. The colorimetric properties of the spectrum. Philosophical Transactions of the Royal Society of London A: Mathematical, Physical and Engineering Sciences, 230(681-693):149-187, 1932. ISSN 0264-3952. doi: 10.1098/rsta.1932.0005. URL http://rsta.royalsocietypublishing.org/content/230/681-693/149.

Christiane Hellmanzik. Historic art exhibitions and modern day auction results. Unpublished manuscript, 2016.

Jacqueline Lichtenstein. The eloquence of color: Rhetoric and painting in the French classical age, volume 18. Univ of California Press, 1993.

Margaret Livingstone and David Hubel. Segregation of form, color, movement, and depth: Anatomy, physiology, and perception. Science, 240(4853):740-749, 1988.

James E Pesando and Pauline M Shum. The returns to picasso's prints and to traditional financial assets, 1977 to 1996. Journal of cultural economics, 23(3):181-190, 1999.

Merijn Rengers and Olav Velthuis. Determinants of prices for contemporary art in dutch galleries, 1992-1998. Journal of Cultural Economics, 26(1):1-28, 2002.

Luc Renneboog and Tom Van Houtte. The monetary appreciation of paintings: From realism to magritte. Cambridge Journal of Economics, 26(3):331-358, 2002.

Elana Stepanova. Impact of color palette on prices of paintings: Picasso at auction. Unpublished Manuscript, 2016.

Heinrich W Ursprung and Christian Wiermann. Reputation, price, and death: an empirical analysis of art price formation. Economic Inquiry, 49(3):697-715, 2011.

Olav Velthuis. Symbolic meanings of prices: Constructing the value of contemporary art in amsterdam and new york galleries. Theory and society, 32(2):181-215, 2003.

Johann Wolfgang von Goethe and Charles Lock Eastlake. Goethe's Theory of Colours: Translated from the German. Murray, 1840. 


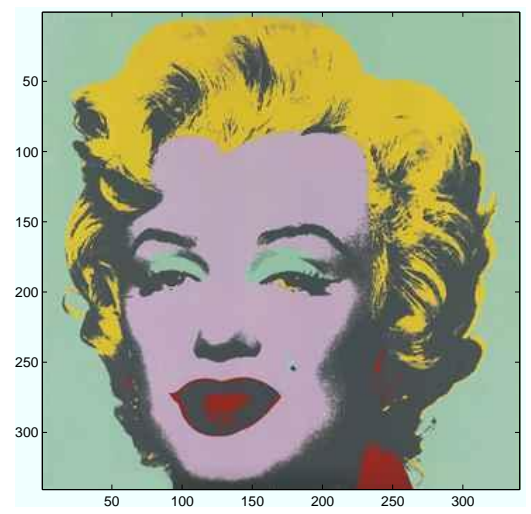

Figure 1: Digital image of Marilyn by Andy Warhol.

Marilyn sold at auction in 2012. The image provides an example of the original digital image as shown in the auction catalogue.
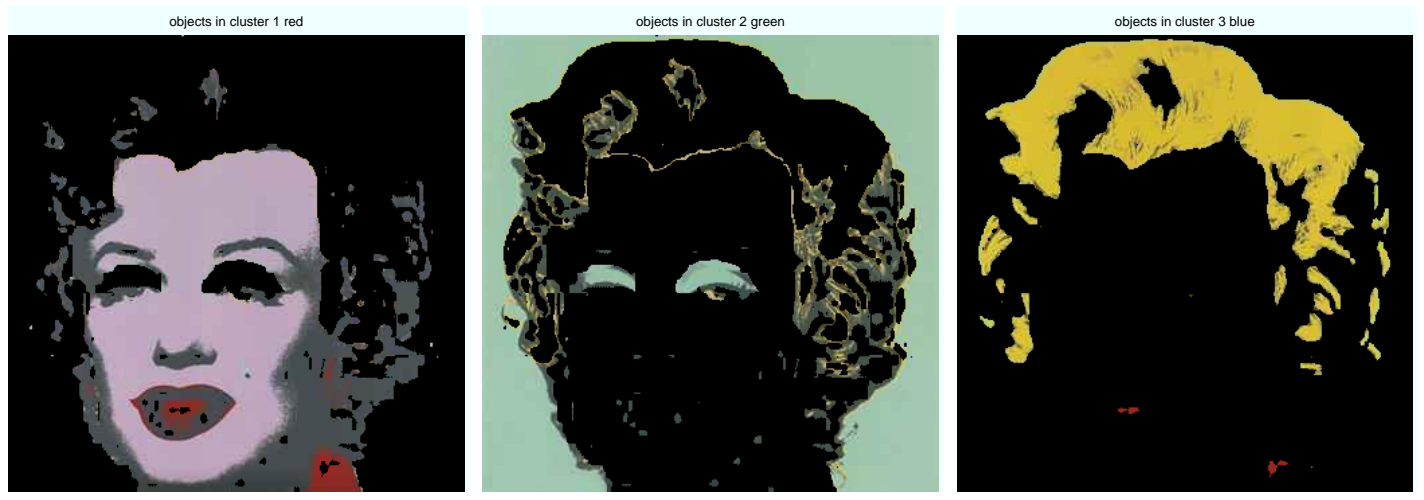

Figure 2: Digital image of Marilyn by Andy Warhol.

The digital figure expresses the RGB color images for the clusters, red, green and blue separately across the three panels. 

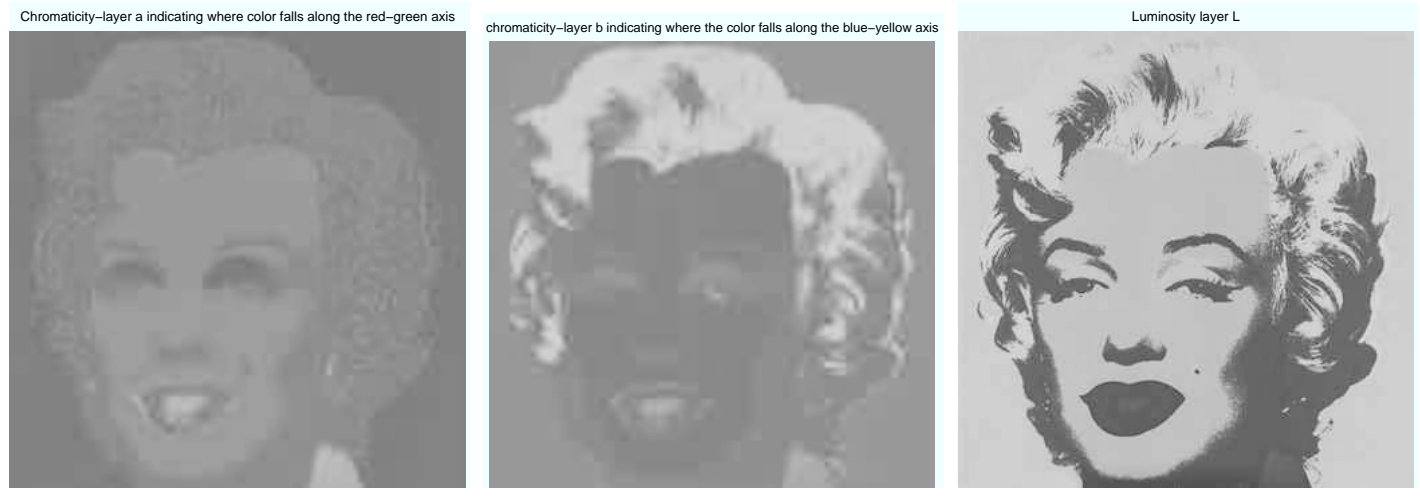

Figure 3: Digital image of Marilyn by Andy Warhol.

The digital figure expresses the layers of the Marilyn digital image according to luminosity, the red-green layer, and the blue-yellow layer, across the three panels.

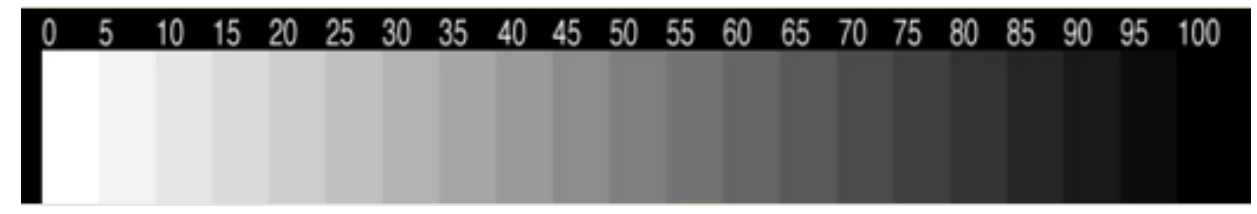

Figure 4: Grayscale

The figure depicts a grayscale from 0 to 100 representing white through to black.

Each block of shading refers to a $5 \%$ increase in the shading. 
Table 1: Summary Statistics

\begin{tabular}{lcccc}
\hline & Variable & Mean & Std. Dev. & Min. Max. \\
\hline Price in $\$$ & 41095.251 & 42892.651 & 2250 & 218500 \\
Log Price & 10.165 & 0.975 & 7.72 & 12.29 \\
Edition max & 187.494 & 193.844 & 1 & 2000 \\
Red & 145.039 & 49.211 & 24 & 236 \\
Green & 128.219 & 43.998 & 22 & 224 \\
Blue & 118.483 & 41.264 & 22 & 225 \\
Observations & 178 & & & \\
\hline
\end{tabular}


Table 2: Log Art Prices and RGB Pixels

\begin{tabular}{|c|c|c|c|c|}
\hline VARIABLES & $\begin{array}{c}(1) \\
\text { Inprice }\end{array}$ & $\begin{array}{c}(2) \\
\text { lnprice }\end{array}$ & $\begin{array}{c}(3) \\
\text { Inprice }\end{array}$ & $\begin{array}{c}(4) \\
\text { lnprice }\end{array}$ \\
\hline Red & $\begin{array}{l}-0.00291^{*} \\
(0.00148)\end{array}$ & & & $\begin{array}{l}-0.00142 \\
(0.00235)\end{array}$ \\
\hline Green & & $\begin{array}{c}-0.00354^{* *} \\
(0.00164)\end{array}$ & & $\begin{array}{r}-0.000378 \\
(0.00382)\end{array}$ \\
\hline Blue & & & $\begin{array}{c}-0.00364^{* *} \\
(0.00176)\end{array}$ & $\begin{array}{l}-0.00229 \\
(0.00322)\end{array}$ \\
\hline Log Edition & $\begin{array}{c}-0.0909 * \\
(0.0519)\end{array}$ & $\begin{array}{c}-0.0971^{*} \\
(0.0520)\end{array}$ & $\begin{array}{l}-0.0947^{*} \\
(0.0514)\end{array}$ & $\begin{array}{c}-0.0964^{*} \\
(0.0523)\end{array}$ \\
\hline Log Size & $\begin{array}{c}0.552^{* * *} \\
(0.184)\end{array}$ & $\begin{array}{c}0.558^{* * *} \\
(0.174)\end{array}$ & $\begin{array}{c}0.588^{* * *} \\
(0.167)\end{array}$ & $\begin{array}{c}0.556^{* * *} \\
(0.173)\end{array}$ \\
\hline Log Age & $\begin{array}{c}1.274^{* * *} \\
(0.419)\end{array}$ & $\begin{array}{c}1.303^{* * *} \\
(0.414)\end{array}$ & $\begin{array}{c}1.300^{* * *} \\
(0.412)\end{array}$ & $\begin{array}{c}1.306^{* * *} \\
(0.417)\end{array}$ \\
\hline London & $\begin{array}{c}0.335 \\
(0.216)\end{array}$ & $\begin{array}{l}0.379^{*} \\
(0.215)\end{array}$ & $\begin{array}{c}0.348 \\
(0.215)\end{array}$ & $\begin{array}{c}0.348 \\
(0.219)\end{array}$ \\
\hline New York & $\begin{array}{l}0.0900 \\
(0.217)\end{array}$ & $\begin{array}{c}0.109 \\
(0.219)\end{array}$ & $\begin{array}{c}0.118 \\
(0.218)\end{array}$ & $\begin{array}{c}0.108 \\
(0.217)\end{array}$ \\
\hline Christie's & $\begin{array}{c}0.120 \\
(0.179)\end{array}$ & $\begin{array}{c}0.107 \\
(0.182)\end{array}$ & $\begin{array}{c}0.116 \\
(0.181)\end{array}$ & $\begin{array}{c}0.121 \\
(0.182)\end{array}$ \\
\hline Sotheby's & $\begin{array}{c}0.171 \\
(0.187)\end{array}$ & $\begin{array}{c}0.145 \\
(0.186)\end{array}$ & $\begin{array}{c}0.185 \\
(0.185)\end{array}$ & $\begin{array}{c}0.177 \\
(0.194)\end{array}$ \\
\hline Constant & $\begin{array}{c}1.407 \\
(2.453)\end{array}$ & $\begin{array}{c}1.307 \\
(2.384)\end{array}$ & $\begin{array}{c}1.020 \\
(2.354)\end{array}$ & $\begin{array}{c}1.365 \\
(2.369)\end{array}$ \\
\hline $\begin{array}{l}\text { Observations } \\
\text { R-squared }\end{array}$ & $\begin{array}{c}178 \\
0.218\end{array}$ & $\begin{array}{c}178 \\
0.221\end{array}$ & $\begin{array}{c}178 \\
0.221\end{array}$ & $\begin{array}{c}178 \\
0.225\end{array}$ \\
\hline
\end{tabular}


Table 3: Log Art Prices and L*a*b Layers

\begin{tabular}{|c|c|c|c|c|}
\hline VARIABLES & $\begin{array}{c}(1) \\
\text { lnprice }\end{array}$ & $\begin{array}{c}(2) \\
\text { lnprice }\end{array}$ & $\begin{array}{c}(3) \\
\text { lnprice }\end{array}$ & $\begin{array}{c}(4) \\
\text { lnprice }\end{array}$ \\
\hline L_mean & $\begin{array}{c}-0.00375^{* *} \\
(0.00171)\end{array}$ & & & $\begin{array}{c}-0.00420^{* *} \\
(0.00184)\end{array}$ \\
\hline a_mean & & $\begin{array}{c}-0.000763 \\
(0.00618)\end{array}$ & & $\begin{array}{l}-0.00288 \\
(0.00640)\end{array}$ \\
\hline b_mean & & & $\begin{array}{l}0.000916 \\
(0.00579)\end{array}$ & $\begin{array}{c}0.00541 \\
(0.00615)\end{array}$ \\
\hline Log Edition & $\begin{array}{c}-0.0970^{*} \\
(0.0517)\end{array}$ & $\begin{array}{l}-0.0799 \\
(0.0511)\end{array}$ & $\begin{array}{l}-0.0803 \\
(0.0511)\end{array}$ & $\begin{array}{c}-0.0982^{*} \\
(0.0518)\end{array}$ \\
\hline Log Size & $\begin{array}{c}0.550 * * * \\
(0.177)\end{array}$ & $\begin{array}{c}0.636^{* * *} \\
(0.180)\end{array}$ & $\begin{array}{c}0.641^{* * *} \\
(0.177)\end{array}$ & $\begin{array}{c}0.561^{* * *} \\
(0.172)\end{array}$ \\
\hline Log Age & $\begin{array}{c}1.305^{* * *} \\
(0.417)\end{array}$ & $\begin{array}{c}1.213^{* * *} \\
(0.420)\end{array}$ & $\begin{array}{c}1.216^{* * *} \\
(0.420)\end{array}$ & $\begin{array}{c}1.310^{* * *} \\
(0.416)\end{array}$ \\
\hline London & $\begin{array}{l}0.371^{*} \\
(0.215)\end{array}$ & $\begin{array}{c}0.332 \\
(0.217)\end{array}$ & $\begin{array}{c}0.334 \\
(0.219)\end{array}$ & $\begin{array}{c}0.349 \\
(0.219)\end{array}$ \\
\hline New York & $\begin{array}{c}0.102 \\
(0.218)\end{array}$ & $\begin{array}{l}0.0966 \\
(0.218)\end{array}$ & $\begin{array}{l}0.0996 \\
(0.219)\end{array}$ & $\begin{array}{c}0.112 \\
(0.217)\end{array}$ \\
\hline Christie's & $\begin{array}{c}0.111 \\
(0.180)\end{array}$ & $\begin{array}{c}0.101 \\
(0.185)\end{array}$ & $\begin{array}{c}0.100 \\
(0.184)\end{array}$ & $\begin{array}{c}0.116 \\
(0.181)\end{array}$ \\
\hline Sotheby's & $\begin{array}{c}0.154 \\
(0.186)\end{array}$ & $\begin{array}{c}0.173 \\
(0.193)\end{array}$ & $\begin{array}{c}0.173 \\
(0.186)\end{array}$ & $\begin{array}{c}0.178 \\
(0.191)\end{array}$ \\
\hline Constant & $\begin{array}{c}1.454 \\
(2.395)\end{array}$ & $\begin{array}{c}0.586 \\
(2.540)\end{array}$ & $\begin{array}{c}0.300 \\
(2.523)\end{array}$ & $\begin{array}{c}1.028 \\
(2.491)\end{array}$ \\
\hline Observations & 178 & 178 & 178 & 178 \\
\hline R-squared & 0.223 & 0.200 & 0.200 & 0.227 \\
\hline
\end{tabular}


Table 4: Log Art Prices and Grayscale

\begin{tabular}{lcc}
\hline VARIABLES & $(1)$ & $(2)$ \\
lnprice & lnprice \\
\hline Gray Mean & & $-0.00385^{* *}$ \\
& & $(0.00172)$ \\
Gray St dev & & 0.00314 \\
& & $(0.00372)$ \\
Log Edition & -0.0802 & $-0.0982^{*}$ \\
& $(0.0509)$ & $(0.0516)$ \\
Log Size & $0.637^{* * *}$ & $0.533^{* * *}$ \\
& $(0.179)$ & $(0.178)$ \\
Log Age & $1.215^{* * *}$ & $1.308^{* * *}$ \\
& $(0.419)$ & $(0.419)$ \\
London & 0.336 & $0.402^{*}$ \\
New York & $(0.216)$ & $(0.216)$ \\
& 0.0975 & 0.127 \\
Christie's & $(0.218)$ & $(0.219)$ \\
& 0.100 & 0.103 \\
Sotheby's & $(0.184)$ & $(0.179)$ \\
& 0.170 & 0.153 \\
Constant & $(0.187)$ & $(0.186)$ \\
& 0.468 & 1.368 \\
Observations & $(2.465)$ & $(2.385)$ \\
R-squared & 0.200 & 0.227 \\
\hline Robust standard errors in parentheses \\
$* * * 0.01, * * \mathrm{p}<0.05, *$ & $\mathrm{p}<0.1$ \\
& &
\end{tabular}

